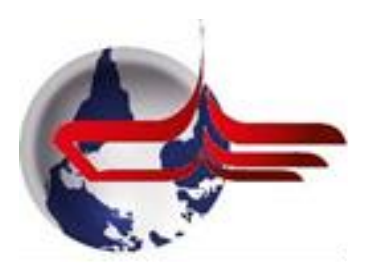

Turkish Journal of Educational Studies, 5 (3) Ekim 2018 Research Article / Araştırma Makalesi

Article Info/Makale Bilgisi

Received/Geliş: Eylül 2018 Accepted/Kabul: Ekim 2018

\title{
İlköğretimde Fen ve Teknoloji Dersini Yürüten Öğretmenlerin Öğretim Sürecinde Yaşadıkları Sorunlar (Elazı̆̆ İli Örneği)*
}

\section{The Problems of Teachers Offering Science and Technology Courses in Primary Schools} İsmail TÜRKOĞLU** Tuğba DAĞ̈**

\section{$\ddot{O} \mathbf{z}$}

$\mathrm{Bu}$ araştırma Elazığ ilindeki ilköğretim fen ve teknoloji dersini yürüten öğretmenlerin öğretim sürecince yaşadıkları sorunları belirlemek amacıyla yapılmıştır. Araştırmanın evrenini, 2011-2012 eğitim ve öğretim yılında Elazığ iline bağlı ilköğretim okullarında görev yapmakta olan öğretmenler; örneklemini ise, Elazığ il ve ilçe merkezlerindeki ilköğretim okullarında rastgele seçilen ve fen bilgisi dersini yürüten 50 öğretmen oluşturmaktadır. Hazırlanan anket ilköğretim birinci kademe 4. ve 5.sınıflarını okutmakta olan sınıf öğretmenleri ile ikinci kademe fen bilgisi derslerini yürüten fen bilgisi öğretmenlerine uygulanmıştır. Araştırmanın bulgularına göre, süreç öncesi ve ölçme değerlendirme aşamalarında fen ve teknoloji öğretmenlerinin sınıf öğretmenlerine oranla daha fazla güçlük yaşadığı, süreçte ise sınıf öğretmenlerinin fen ve teknoloji öğretmenlerine oranla daha fazla güçlük yaşadığı belirlenmiştir. Fen ve teknoloji dersini yürüten öğretmenlerinin uygulamada karşılaştıkları sorunlarda, Fen ve Teknoloji dersi ile ilgili karşılaşılan sorunlarda ve Fen ve teknoloji dersi öğretim programıyla ilgili sorunlarda cinsiyet açısından kadın öğretmenlerin erkek öğretmenlere oranla daha fazla sorun yaşadığı belirlenmiştir. Sıfir-5 yıl ile 16 yıl ve üzeri kıdemi olanlar arasında 0-5 yıl kıdemi olanların lehine, yüksek lisans eğitimi açısından da yüksek lisans yapan öğretmenler lehine anlamlı farklılık belirlenmiştir.

Anahtar Kelimeler: Fen eğitimi, ölçme değerlendirme, öğretim programı

\begin{abstract}
This study was conducted to determine the problems faced by science and technology teachers in primary schools in Elazig. The population of the study was conducted in the 2011-2012 academic year by teachers working in primary schools in the province of Elazig; and the sample consists of 50 randomly selected teachers working in primary schools in Elazig province and district centers. The questionnaire was applied to the classroom teachers teaching the 4 th and 5 th grades of the first stage primary schools and to the science teachers teaching the second stage students.

*Bu makale danışmanlığı İsmail TÜRKOĞLU tarafindan yapilan yüksek lisans tezinden üretilmiştir.

**Doç. Dr., Fırat Üniversitesi Eğitim Fakültesi El-mek: isturkoglu@ firat.edu.tr

*** Fırat Üniversitesi Eğitim Fakültesi Yüksek lisans mezunu
\end{abstract}


According to the findings of the study, it was determined that science and technology teachers experience more difficulties in the pre-process and measurement evaluation stages compared to classroom teachers, while in the process, the classroom teachers experience more difficulties than science and technology teachers. It was determined that female teachers face more problems compared to male teachers in terms of science and technology course, practice process of this course and its curriculum. A significant difference was determined in favor of teachers who have a seniority of 0-5 years compared to ones who have 16 or more years of seniority and in favor of those who hold a master's degree.

Key Words: Primary schools, science education, testing and evaluation, curriculum

\section{GİRIŞ}

İçinde yaşadığımız yüzyıl, ekonomik ve teknolojik yarışın ivme kazandığı yüzyıl olarak tanımlanmaktadır. Bu yarıştan galip çıkacak olanlar da, bilim ve fen alanında başarılı olan uluslardır. Bir ulus bilim ve fen alanında ne kadar ileri ise, ekonomik ve toplumsal yönden de o kadar refaha kavuşmuş demektir. Bu nedenle her ulus, geleceğini görebilmek, ekonomik ve teknolojik yarışta yenilgiye uğramamak için fen bilimlerine önem vermek zorundadır (Akgün, 2000). Okullardaki araçgereçlerin öğretmenler tarafindan kullanılmaması ve öğrencilere deneyler yaptırılmaması, öğrencilerin fen derslerindeki başarılarını olumsuz yönde etkileyerek onların bu dersten soğumalarına sebep olmaktadır. Bu nedenle öğrencilerin fen derslerinin önemini anlaması, istenilen davranışları yasam boyu kalıcı olarak göstermesi ve bunları geliştirebilmesi için fen konuları ile iç içe olmasını, somut yaşantılar kazanmasını sağlamak önem kazanmaktadır (Oğuz, 1993). Araştırma bulguları, yaparak-yasayarak öğrenmeyi sağlayan araç ve yöntemlerin kullanıldığı okullarda bilimsel bilgileri kazanma yollarının daha iyi öğrenildiğini göstermektedir (Çilenti, 1984).

Fen bilimleri eğitiminin temel amaçlarından biri öğrencileri bilimsel olarak okuryazar düzeye getirmektir. Bilimsel okuryazarlık; fen bilimlerinin doğasını bilmek, bilginin nasıl elde edildiğini anlamak, fen bilimlerindeki bilgilerin bilinen gerçeklere bağlı olduğunu ve yeni kanıtlar toplandıkça değişebileceğini kabul edebilmek, fen bilimlerindeki temel kavramları, teori ve hipotezleri kavramak, bilimsel kanıt ile kişisel görüş arasındaki farkı algılamak olarak tanımlanmaktadır. Bilimsel okuryazar bireylerden oluşan toplumlar hem yeniliklere kolayca uyum sağlar, hem de kendileri yeniliklere önderlik edebilirler (Soylu, 2004)

Öğrencilerin fen kavramlarıyla ilgili ilk sistematik öğrenmeleri ilköğretim 4. sinıfta Fen ve Teknoloji derslerinde baslar. Ancak öğrencilerin bundan önce kazandıkları birikimler sonraki öğrenmelerini anlamlı kılması açısından son derece büyük önem taşımaktadır. İlköğretim 4. ve 5.sınıf öğrencileri günlük yaşantılarından edindikleri bazı yanlış bilgiler nedeniyle kavram yanılgılarına sahip olabilmektedirler. Bu yıllarda oluşacak kavram yanılgıları bundan sonraki öğrenmelerini de olumsuz yönde etkileyecek ve tespit edilerek değiştirilmesi zor olacaktır (Nakipoğlu ve Özkılıç, 2006). Öğretmenler bu kavram yanılgılarını ortaya çıkarıcı yöntem ve teknikler uygulamalıdır. Fen ve Teknoloji eğitiminde yöntem ve tekniklerin kullanımı kadar bu yöntem ve teknikleri uygulayan 
öğretmenin donanımlı olması da önemlidir. Genel kültür bilgisi, alanıyla ilgili bilgi ve becerisi, ayrıca öğrenme sürecini planlama ve uygulama becerisi öğretmenin yeterliğini ortaya koyar. $\mathrm{Bu}$ aşamada öğretmen yetiştiren kurumlara da büyük görev düşmektedir. Özellikle ezbercilikten uzak daha çok araştırma ve uygulamaya dönük eğitimler verilmelidir.

İlköğretim fen konularının öğretimi, 1. 2. 3. sınıflarda Hayat bilgisi, 4.5 .67 ve 8. sınıflarda ise Fen ve Teknoloji dersleri içinde yapılmaktadır. Toplum ve çevre kalkınmasının temeli, ilk kez ilköğretim kurumlarından fen bilgisi dersleri ile atılır. Bu derste çocuklar, içinde yasadıkları fen ve tabiat dünyasını bilimsel yönden ele ayıp inceleme firsatı elde ederler (Akgün, 1995).

Evreni büyüklügünden ve gizeminden bir şey kaybetmeden görmemizi sağlayan fen bilimleri doğal dünyayı anlamamız için bir sistem ortaya koyar (Atasoy, 2004). Ortaya koyulan bu fen bilimlerinin içeriği ise:

- Olgular

- Kavramlar

- İlkeler ve genellemeler

- Kuramlar ve doğa kuramları şeklindeki farklı yapıdaki bilgilerden oluşmaktadır (Kaptan ve Korkmaz, 2001).

Bireyin hem kendisini anlaması, hem çevresini anlaması hem de çevreye uyum sağlamasında fen biliminin etkisi büyüktür. Günlük yaşamımızda ihtiyaçlardan kaynaklanan birçok sorunun sebebini ve çözüm yolunu bulmamızda Fen biliminden yararlanırız. Günlük hayatımızda bunun farkına varmasak da, düşündügümüzde hemen hemen hayatımızın tamamının fen ile ilgili olduğunun farkına varırız. Özellikle günümüzde teknolojinin ilerlemesiyle birlikte fen günlük yaşantımızın ayrılmaz bir öğesi olmuştur. Evlerimizde kullandığımız elektronik aletler, hava durumunun nasıl olacağı, iletişim araçları, kozmetikler, ısındığımız sobada yaktığımız kömür, saksıda yetiştirdiğimiz çiçek hep fen ile ilgilidir (Kurt, 2001).

Fen bilimleri, fen araştırmacılarının doğayı, doğa olaylarını ve doğal gerçekleri arama gayretleri sonucunda ortaya çıkmıştır. Fen ve Teknoloji öğrenmekle insanlar gözlemlenmemiş bazı olaylar ve olgular hakkında kestirimde bulunabilirler. İnsanlar fen ile ilgili olayları öğrenmekle çevrelerinde olup biten olayları doğru algılar, olabilecek bazı olayları önceden kestirebilir, yaşamı daha kolay ve yaşanabilir duruma getirebilirler. Olay ve olgulara analitik olarak yaklaşır, neden sonuç ilişkilerini daha doğru kurabilirler. Fen'in toplum ilişkilerinde, teknolojide ve bireysel yaşamda neler sağladığı, öğrencinin becerilerine 1şık tuttuğu bilinen bir gerçektir. Fen bilimleri, öğrencilerde yaratıcılık becerileri kazandırmanın yanında iyi bir fen okuryazarı olmayı da sağlar (Temizyürek, 2003).

Program geliştirmedeki yeni yaklaşımlar Fen ve Teknoloji Dersi Öğretim Programını yenileme ihtiyacını doğurmuştur. Ortaya çıkan ihtiyaçlar ışığında Milli Eğitim Bakanlığı Talim ve Terbiye Kurulu Başkanlığınca, “İlköğretim Fen ve Teknoloji Dersi Öğretim Programı” yenilenerek, "Fen Bilimleri Dersi Öğretim Programı” adı altında uygulamaya konulmuştur. Fen Bilimleri Dersi Öğretim Programı'nda öğrenme-öğretme kuram ve uygulamaları açısından bütüncül bir bakış açısı benimsenmiş; 
genel olarak öğrencinin kendi öğrenmesinden sorumlu olduğu, öğrenme sürecine aktif katılımının sağlandığı, araştırma-sorgulama ve bilginin transferine dayalı öğrenme stratejisi esas alınmıştır. Öğrenme-öğretme sürecinde öğretmen; teşvik edici, yönlendirici rollerini üstlenirken öğrenci; bilginin kaynağını araştıran, sorgulayan, açıklayan, tartışan ve ürüne dönüştüren birey rolünü üstlenir. $\mathrm{Bu}$ süreçte, fen bilimlerinin matematik, teknoloji ve mühendislikle bütünleştirilmesi sağlanarak öğrencilerin problemlere disiplinler arası bakış açısıyla bakması hedeflenir. Bu bağlamda öğretmenlerin rolü öğrencilere fen, teknoloji, mühendislik ve matematiğin bütünleştirilmesi için rehberlik yaparak öğrencileri üst düzey düşünme, ürün geliştirme, buluş ve inovasyon yapabilme seviyesine ulaştırmaktır (Fen Bilimleri Dersi Öğretim Programı, 2018).

Öğrencilerin fen kavramlarıyla ilgili ilk sistematik öğrenmeleri ilköğretim 4. sınıfta Fen ve Teknoloji derslerinde başlar. Ancak öğrencilerin bundan önce kazandıkları birikimler sonraki öğrenmelerini anlamlı kılması açısından son derece büyük önem tanımaktadır. İlköğretim 4. ve 5.sınıf öğrencileri günlük yaşantılarından edindikleri bazı yanlış bilgiler nedeniyle kavram yanılgılarına sahip olabilmektedirler. Bu yıllarda oluşacak kavram yanılgıları bundan sonraki öğrenmelerini de olumsuz yönde etkileyecek ve tespit edilerek değiştirilmesi zor olacaktır (Nakipoğlu ve Özkılıç, 2006).

Öğretmenler bu kavram yanılgılarını ortaya çıkarıcı yöntem ve teknikler uygulamalıdır. Fen ve Teknoloji eğitiminde yöntem ve tekniklerin kullanımı kadar bu yöntem ve teknikleri uygulayan öğretmenin donanımlı olması da önemlidir. Genel kültür bilgisi, alanıyla ilgili bilgi ve becerisi, ayrıca öğrenme sürecini planlama ve uygulama becerisi öğretmenin yeterliğini ortaya koyar. $\mathrm{Bu}$ aşamada öğretmen yetiştiren kurumlara da büyük görev düşmektedir. Özellikle ezbercilikten uzak daha çok araştırma ve uygulamaya dönük eğitimler verilmelidir. Ülke kalkınmasını ön plana çıkaran toplumlar, eğitime büyük önem vermektedir. Eğitim ise belirli amaçlar doğrultusunda yapılan etkinlikleri içerdiği için, bu etkinliklerin amaçlar doğrultusunda planlanmış programlar çerçevesinde, formal eğitim yolu ile verilmesi gerekmektedir. Formal eğitimin verildiği yer ise okul denilen kurumlardır. Okulun görevi, hem toplumun kültürel yapısını bir sonraki kuşaklara aktarmak hem de mevcut kültürü çağın gereklerine göre geliştirmektir.

Başaran (1988)'a göre “öğretmen, öğrencilerin davranışları üzerinde çalışır, eğittiği her ögrencisinin önceden saptanmış amaçlara ulaşmasına yardım eder ve onların istenilen davranışlara sahip birer kişi olmasını sağlar. Bu anlamda öğretmen, öğrencisinin davranışlarının mimarıdır”. Çevre ile uyumlu, çevrenin sorunlarını araştırıp bu sorunları keşfeden ayrıca bilim ve teknolojiyi takip edip, kullanarak problemleri çözebilen bireyler yetiştirebilmek için Fen ve Teknolojiye büyük önem vermeliyiz. Bu araştırmanın Fen ve Teknoloji eğitiminde karşılaşılan sorunları ortaya koymamızda ve daha nitelikli bir fen öğretimi gerçekleşmesinde yardımcı olacağına inanılmaktadır.

$\mathrm{Bu}$ çalışmanın amacı Elazığ ilindeki İlköğretim fen ve teknoloji dersini yürüten öğretmenlerin öğretim sürecince yaşadıkları sorunları belirlemektir. Bu amaçla aşağıdaki sorulara cevap aranmıştır.

1. Fen ve Teknoloji dersini yürüten öğretmenlerinin uygulamada karşılaştıkları sorunlar, fen ve teknoloji dersi ile ilgili karşılaşılan sorunlar ve fen ve teknoloji dersi öğretim programıyla ilgili sorunlar 
nelerdir?

2. Bu sorunlar branş, cinsiyet, yüksek lisans eğitimi, mesleki kıdem, görev yeri ve öğrenim durumu değişkenleri açısından anlamlı bir farklılık göstermekte midir?

\section{YÖNTEM}

$\mathrm{Bu}$ araştırmada, öğretmenlerin görüşlerini doğrudan öğrenmeye yönelik tarama modeli kullanılmıştır. Araştırmanın çalışma evrenini, Elazığ ilindeki ilköğretim okullarında 2011-2012 eğitim ve ögretim döneminde görev yapmakta olan Fen ve Teknoloji öğretmenleri ile 4. ve 5. sinıfları okutmakta olan sınıf öğretmenleri oluşturmaktadır. Çalışma evrenini temsil etmek üzere, Elazığ il merkezinden rastgele seçilen 20 ilköğretim okulundaki fen bilgisi dersini yürüten öğretmenler örneklem olarak belirlenmiştir. Sınıf öğretmenliği branşından 31, Fen ve Teknoloji öğretmenliği branşından ulaşılan 19 öğretmene hazırlanan anket uygulanmıştır.

Anket formu iki bölümden meydana gelmektedir. İlk bölümde öğretmenlere ait kişisel bilgiler yer almaktadır. İkinci bölüm ise beş alt bölümden meydana gelmektedir. Birinci alt bölümde; süreç öncesi hazırlıkta karşılaşılan sorunlara değinilmiştir. Bu kapsamda ders öncesi gerekli hazırlığın yapılması, hazırlığın kılavuz kitap çerçevesinde yapılması, programda yer alan kazanımların net bir şekilde anlaşılıp anlaşılmadığı, etkinliklerin birden çok duyu organına göre çeşitlendirilebilmesi, öğrenci tutumlarının belirlenmesi, öğrencilerin ilgilerinin belirlenmesi, öğrencilerin çalışma alışkanlıklarının tespit edilmesi, kazanımlara uygun yöntem seçimi ve öğrenci özelliklerine uygun yöntem seçimi konusunda yaşanılan sorunlar belirlenmeye çalışılmıştır. İkinci alt bölümde; süreçte karşılaşılan sorunlara değinilmiştir. Bu kapsamda sadece programın ya da kılavuz kitabın dikkate alınması, öğrencilerin çalıştıkları konuların alt konulara ayrılmasında, değerlendirmenin amacı ve ölçütlerini belirlemelerinde öğretmenlerin etkisi, kendi öğrenme ve problem çözme yöntemine karar verebilmelerinde öğretmenlerin etkisi, öğrencilerin ön bilgilerinin açığa çıkarılması, öğrencilerin ilgi uyandıran problemlere yönlendirilebilmesi, öğrencilere üst düzey düşünme becerilerini geliştiren problemler sorulması, öğrencilerin kendi etkinliklerini-projelerini planlamalarını sağlama, öğrencilerin öğrenme süresi ile gerçek yaşam arasında bağlantı kurabilmesini sağlama, özel öğretime ihtiyacı olan öğrencilere öğretim ekinliklerinde rehberlik etme konusunda yaşanılan sorunlar belirlenmeye çalışılmıştır. Üçüncü alt bölümde; ölçme değerlendirme etkinliklerinde karşıllaşılan sorunlara değinilmiştir. $\mathrm{Bu}$ kapsamda programda ölçme değerlendirme etkinliği verilmeyen kazanımlarda değerlendirme etkinliği tasarlama, tamamlayıcı ölçme değerlendirme etkinliklerini uygulama, öğrenci gelişimlerini takip etme, her öğrenci için ders süresinde kayıt tutabilme, değerlendirme sonuçlarını programa yansıtma öğrencilerin kendi kendini değerlendirme formlarını doldurmadaki isteklilikler, velilere doldurmaları için verilen değerlendirme formlarının geri dönüşlerinde yaşanan sorunlar belirlenmeye çalışılmıştır. Dördüncü alt bölümde; fen ve teknoloji dersi ile ilgili karşılaşılan sorunlara değinilmiştir. Bu kapsamda okulun laboratuar olanaklarının yeterliliği, sınıf mevcuduna paralel araçgereç yeterliliği, okuldaki görsel ve işitsel teknolojik araçların yeterliliği, öğretmenlerin ölçme 
değerlendirme konusundaki yeterliliği, programdaki ölçme değerlendirme etkinliklerinin anlaşılabilirliği konusunda yaşanan sorunlar belirlenmeye çalışılmıştır. Beşinci alt bölümde ise fen ve teknoloji dersi öğretim programı ile ilgili karşılaşılan sorunlara değinilmiştir. Bu kapsamda, FenTeknoloji-Toplum-Çevre kazanımlarının yeterliliği, etkinliklerin uygulanabilmesi için zamanın yeterliliği, öğretmenlerin teknolojik araç ve gereçlerin kullanımı konusunda ve öğrenci merkezli öğretim uygulamaları konusundaki yeterlilikleri, öğrencilerin girdikleri LYS gibi sınavların programla örtüşebilirliği, değerlendirme basamaklarının yeterliliği, ek kaynakların yasaklanması sonucunda yaşanan sorunlar, konularla ilgili anlatımların anlaşılırlığı ve öğrenci seviyesine uygunluğu konusunda yaşanan sorunlar belirlenmeye çalışılmıştır. Veri toplama aracı toplam 45 maddeden oluşan 3'lü likert tipi bir ölçektir. Ölçeğin puanlandırılması "Evet" 3 puan, "Kısmen" 2 puan, "Hayır" 1 puan şeklindedir. Ölçeğin geneli için güvenirlik katsayısı .89 olarak hesaplanmıştır.

Öğretmenlerin Fen ve Teknoloji dersi öğretim süreci öncesinde, öğretim sürecinde, ölçme değerlendirme sürecinde, Fen ve Teknoloji dersinde, Fen ve Teknoloji dersi öğretim programında yaşadıkları sorunların güçlük düzeylerinin branşa (Fen ve Teknoloji öğretmeni - Sınıf öğretmeni), cinsiyete (Kadın - Erkek), lisans üstü eğitim yapma durumuna göre, öğretmenlerin görev yerine göre istatistikî olarak değişip değişmediğini test etmek için t-testi kullanılmıştır. Mesleki kıdem (0- 5 yıl, 610 yıl, 11-15 yıl, 16 yıl ve üzeri) ve eğitim durumuna göre (Sınıf öğretmenliği, Fen ve Teknoloji öğretmenliği, Eğitim yüksekokulları, Eğitim yüksekokulları + Lisans tamamlama, İki yıllık eğitim enstitüsü, İki yıllık eğitim enstitüsü + Lisans tamamlama, Eğitim fakültesi dışındaki branş öğretmenlikleri, Eğitim fakültesi dışındaki lisans programları ) istatistikî olarak değişip değişmediğini test etmek için ANOVA kullanılmıştır.

\section{BULGULAR}

Araştırmadan elde edilen bulgular ve bu bulgulara ilişkin yorumlar aşağıda verilmiştir. Öğretmenlere ait kişisel veriler araştırmaya katılan öğretmenlerin branş değişkenine göre dağılımı Tablo 1 'de verilmiştir.

Tablo 1. Öğretmenlerin branş, cinsiyet ve mesleki kıdem değişkenine göre dağılımı

\begin{tabular}{lll}
\hline Branş & $\mathrm{n}$ & $\%$ \\
\hline Sinı Öğretmeni & 31 & 62 \\
\hline Fen ve Teknoloji Öğretmeni & 19 & 38 \\
\hline Toplam & 50 & 100 \\
\hline Cinsiyet & & \\
\hline Kadın & 27 & 54 \\
\hline Erkek & 23 & 46 \\
\hline Toplam & 50 & 100 \\
\hline Mesleki kıdem & & \\
\hline $0-5$ yll & 6 & 12 \\
\hline $6-10$ yll & 8 & 16 \\
\hline
\end{tabular}




\begin{tabular}{lll}
\hline $11-15$ yil & 15 & 30 \\
\hline 16 y1l ve üzeri & 21 & 42 \\
\hline Toplam & 50 & 100 \\
\hline
\end{tabular}

Tablo 1'de görüldügü öğretmenlerin 31'i (\%62) sınıf öğretmeni, 19'u (\%38) ise fen ve teknoloji öğretmenidir. Öğretmenlerin 27' si (\%54) kadın, 23’ü (\%46) erkektir. Öğretmenlerin 6’s1 (\%12) 0-5 yıl, 8 'i (\%16) 6-10 y11, 15’i (\%30) 11-15 y1l ve 21'i de (\%42) 16 yıl ve üzeri k1deme sahiptir.

Araştırmaya katılan öğretmenlerin görev yerlerine göre dağılımı Tablo 2'de verilmiştir.

Tablo 2. Öğretmenlerin görev yeri ve lisansüstü eğitim değişkenlerine göre dağılımı

\begin{tabular}{lccc}
\hline & Mesleki kidem & $\mathrm{n}$ & $\%$ \\
\hline İl merkezi & 35 & 70 \\
\hline İlçe merkezi & 15 & 30 \\
\hline Toplam & 50 & 100 \\
\hline Lisansüstü eğitim & & \\
\hline Evet & 10 & 20 \\
\hline Hayır & 40 & 80 \\
\hline Toplam & 50 & 100 \\
\hline
\end{tabular}

Tablo 2'de görüldüğü gibi araştırmaya il merkezinden 35, ilçe merkezinden 15 öğretmen katılmıştır. Öğretmenlerden 10’u (\%20) yüksek lisans eğitimi almış, 40’1 (\%80) almamıştır.

Araştırmaya katılan öğretmenlerin eğitim durumları değişkenine göre dağılımı Tablo 3'te verilmiştir.

Tablo 3. Öğretmenlerin eğitim durumları değişkenine göre dağılımı

\begin{tabular}{lcc}
\hline Eğitim Fakültesi Bölümleri & $\mathrm{n}$ & $\%$ \\
\hline Sınıf öğretmenliği & 13 & 26 \\
\hline Fen ve teknoloji öğretmenliği & 9 & 18 \\
\hline Eğitim fakültesi dışındaki branş öğretmenliği & 6 & 15 \\
\hline Eğitim Fakültesi Dışındaki Bölümler & 4 & 8 \\
\hline Eğitim Yüksekokulu & 2 & 4 \\
\hline Eğitim Yüksekokulu +Lisans tamamlama & 3 & 6 \\
\hline İki yıllık eğitim enstitüsü & 10 & 20 \\
\hline Eğitim fakültesi dışı lisans programı & 3 & 6 \\
\hline Diğer & 50 & 100 \\
\hline Toplam & & \\
\hline
\end{tabular}

Tablo 3'te görüldüğü gibi, Fen ve Teknoloji dersini yürüten öğretmenlerin; 13'ü (\%26) sinıf öğretmenliği, 9'u (\%18) fen ve teknoloji öğretmenliği, 6's1 (\%15) eğitim fakültesi dışındaki branş öğretmenliği, 4’ü (\%8) eğitim yüksekokulu, 2'si (\%4) eğitim yüksekokulu+lisans tamamlama, 3'ü (\%6) iki yıllık eğitim enstitüsü, 10’u (\%20) eğitim fakültesi dışındaki lisans programları ve 3'ü de (\%6) diğer 
programlardan mezun olmuştur.

Fen ve Teknoloji dersini yürüten öğretmenlerinin uygulamada karşılaştıkları sorunlar, fen ve teknoloji dersi ile ilgili karşılaşılan sorunlar ve fen ve teknoloji dersi öğretim programıyla ilgili sorunlara ilişkin görüşleri ile branş değişkeni arasında anlamlı bir farklılık var mıdır?

Branş değişkenine göre öğretmenlerin fen ve teknoloji dersi ile ilgili yaşadıkları sorunların güçlük düzeylerine ilişkin t-testi sonuçları Tablo 4’te verilmiştir.

Tablo 4. Öğretmenlerin branşlarına göre yaşadıkları sorunların güçlük düzeyleri

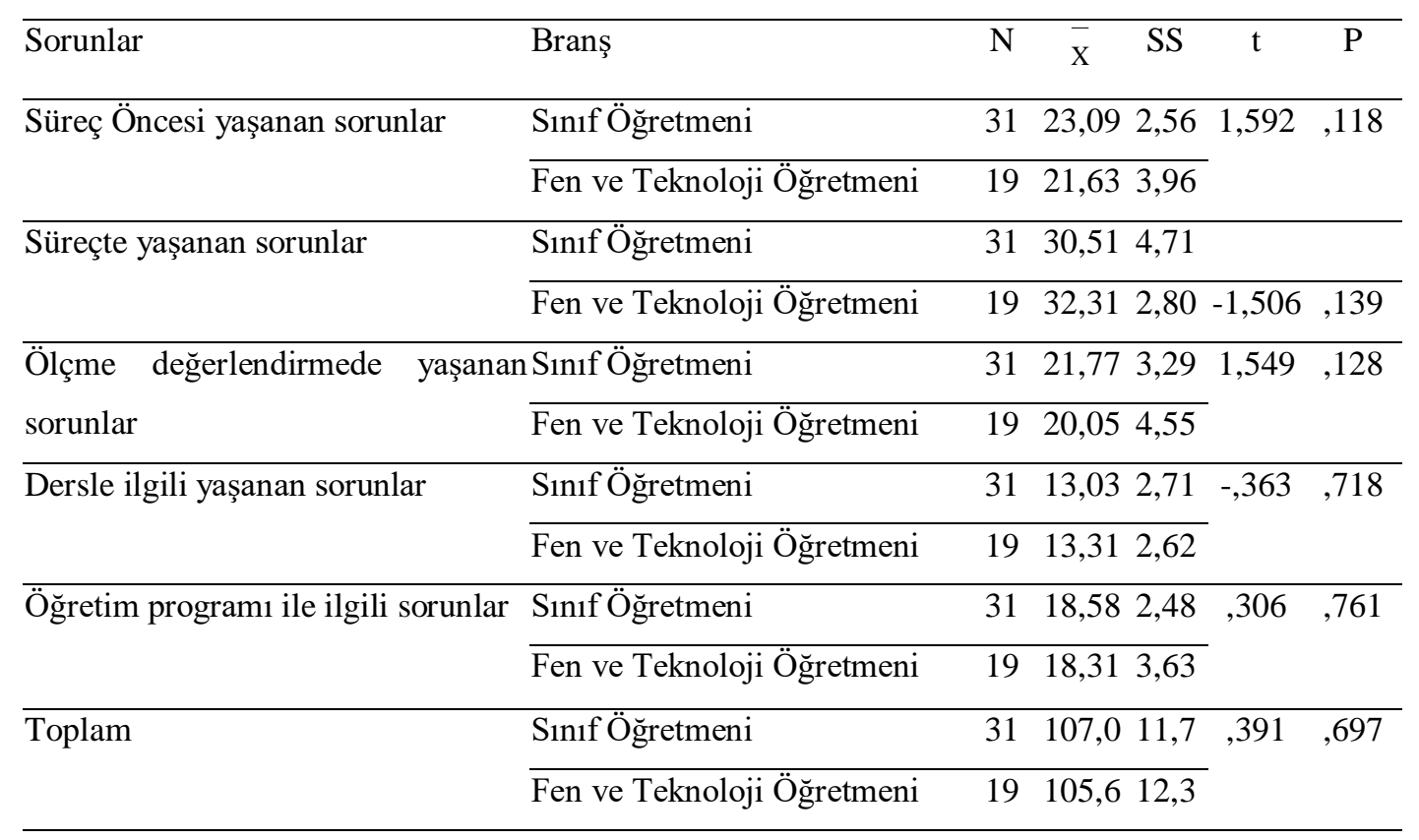

Tablo 4'e göre, sınıf öğretmenleri ile fen ve teknoloji öğretmenlerinin süreç öncesinde, süreçte, ölçme değerlendirmede, fen ve teknoloji dersinde ve öğretim programında yaşanan sorunlara ilişkin puanları arasında anlamlı bir farklılık görülmemektedir ( $\mathrm{p}>0,05)$.

Fen ve Teknoloji dersini yürüten öğretmenlerinin uygulamada karşılaştıkları sorunlar (Süreç öncesi hazırlıkta karşılaşılan sorunlar, süreçte karşılaşılan sorunlar ve ölçme değerlendirme etkinliklerinde karşılaşılan sorunlar), fen ve teknoloji dersi ile ilgili karşılaşılan sorunlar ve fen ve teknoloji dersi öğretim programıla ilgili sorunlara ilişkin görüşleri ile cinsiyet değişkeni arasında anlamlı bir farklılık var mıdır?

Tablo 5. Öğretmenlerin cinsiyetlerine göre yaşadıkları sorunların güçlük düzeyleri

\begin{tabular}{llllllll}
\hline & & N & $\bar{X}$ & SS & T & p \\
Süreç Öncesi Sorunlar & Kadın & 27 & 22,44 & 2,83 &,- 226 &, 822 \\
& Erkek & 23 & 22,65 & 3,66 & & \\
\hline Süreçte Sorunlar & Kadın & 27 & 30,74 & 4,31 &,- 844 &, 403 \\
& Erkek & 23 & 31,73 & 3,99 & & \\
\hline Ölçme Değerlendirmede Yaşanan Sorunlar & Kadın & 27 & 20,40 & 3,50 & $-1,426$ &, 160
\end{tabular}




\begin{tabular}{lllllll}
\hline & Erkek & 23 & 21,95 & 4,18 & \\
\hline Dersle ilgili Yaşanan Sorunlar & Kadın & 27 & 12,92 & 2,88 & -613 & ,543 \\
& Erkek & 23 & 13,39 & 2,40 & & \\
\hline Öğretim Programı ile İlgili sorunlar & Kadın & 27 & 17,70 & 3,07 & $-2,089$ &, 042 \\
& Erkek & 23 & 19,39 & 2,55 & & \\
\hline Toplam & Kadın & 27 & 104,2 & 11,32 & $-1,471$ &, 148 \\
& Erkek & 23 & 109,1 & 12,25 & & \\
\hline
\end{tabular}

Tablo 5'e göre, öğretim programı ile ilgili sorunlar alt boyutunda kadın öğretmenler ile erkek ögretmenlerin puan ortalamaları arasında anlamlı fark bulunmuştur $(\mathrm{p}<0.05)$. Öğretim programı ile ilgili sorunlar alt boyutunda kadın öğretmenlerin erkeklere oranla daha az sorun yaşadığı görülmektedir. Diğer alt boyutlar için anlamlı bir farklılık yoktur.

Fen ve Teknoloji dersini yürüten öğretmenlerinin uygulamada karşılaştıkları sorunlar, fen ve teknoloji dersi ile ilgili karşılaşılan sorunlar ve fen ve teknoloji dersi öğretim programıyla ilgili sorunlara ilişkin görüşleri ile yüksek lisans yapıp yapmadıklarına ilişkin değişken arasında anlamlı bir farklılık var midir?

Öğretmenlerin fen ve teknoloji dersi ile ilgili yaşadıkları sorunların güçlük düzeylerinin yüksek lisans eğitimine göre t-testi sonuçları Tablo 6'da verilmiştir.

Tablo 6. Öğretmenlerin yüksek lisans yapıp yapmadıklarına göre yaşadıkları sorunların güçlük düzeyleri

\begin{tabular}{|c|c|c|c|c|c|}
\hline & Yüksek Lisans & $\mathrm{n}$ & $\mathrm{X}$ & SS & $\mathrm{p}$ \\
\hline \multirow[t]{2}{*}{ Süreç öncesi sorunlar } & Evet & 10 & 24,10 & 2,37 & $1,755,086$ \\
\hline & Hayır & 40 & 22,15 & 3,29 & \\
\hline \multirow[t]{2}{*}{ Süreçte sorunlar } & Evet & 10 & 32,90 & 2,18 & $1,463,150$ \\
\hline & Hayır & 40 & 30,77 & 4,43 & \\
\hline \multirow[t]{2}{*}{ Ölçme değerlendirmede yaşanan sorunlar } & Evet & 10 & 22,30 & 2,75 & $1,080,285$ \\
\hline & Hayır & 40 & 20,82 & 4,07 & \\
\hline \multirow[t]{2}{*}{ Dersle ilgili yaşanan sorunlar } & Evet & 10 & 14,30 & 2,58 & $1,566,124$ \\
\hline & Hayır & 40 & 12,85 & 2,62 & \\
\hline \multirow[t]{2}{*}{ Öğretim programı ile ilgili sorunlar } & Evet & 10 & 19,70 & 2,35 & $1,483,145$ \\
\hline & Hayır & 40 & 18,17 & 3,02 & \\
\hline \multirow[t]{2}{*}{ Toplam } & Evet & 10 & 113,3 & 7,68 & $2,095,041$ \\
\hline & Hayır & 40 & 104,7 & 12,2 & \\
\hline
\end{tabular}

Tablo 6'ya göre, Fen ve Teknoloji dersini yürüten öğretmenlerinin uygulamada karşılaştıkları sorunlardan, sadece anketin toplamında yüksek lisans eğitimi açısından anlamlı bir farklılık görülmektedir $(\mathrm{p}<0,05)$. Yüksek lisans yapan öğretmenler yapmayanlara göre yaşadıkları sorunların güçlük düzeyini daha yüksek ifade etmişlerdir. 
Fen ve Teknoloji dersini yürüten öğretmenlerinin uygulamada karşılaştıkları sorunlar, fen ve teknoloji dersi ile ilgili karşılaşılan sorunlar ve fen ve teknoloji dersi öğretim programıyla ilgili sorunlara ilişkin görüşleri ile mesleki kıdem değişkeni arasında anlamlı bir farklılık var mıdır?

Öğretmenlerin fen ve teknoloji dersi ile ilgili yaşadıkları sorunların güçlük düzeylerinin mesleki kıdemlerine göre dağılımları Tablo 7'de verilmiştir.

Tablo 7. Öğretmenlerin mesleki kıdemlerine göre yaşadıkları sorunların güçlük düzeyleri

\begin{tabular}{|c|c|c|c|c|}
\hline & Kidem & $\mathrm{N}$ & $X$ & SS \\
\hline \multirow[t]{4}{*}{ Süreç öncesi sorunlar } & $0-5 \mathrm{y} 1 \mathrm{l}$ & 6 & 22,00 & 3,28 \\
\hline & $6-10$ y1l & 8 & 21,87 & 3,60 \\
\hline & $11-15$ y1l & 15 & 21,73 & 2,84 \\
\hline & 16 yıl ve üzeri & 21 & 23,52 & 3,24 \\
\hline \multirow[t]{4}{*}{ Süreçte sorunlar } & $0-5$ yil & 6 & 29,16 & 6,61 \\
\hline & 6-10 y1l & 8 & 30,75 & 3,24 \\
\hline & $11-15 \mathrm{yll}$ & 15 & 30,80 & 4,45 \\
\hline & 16 yıl ve üzeri & 21 & 32,23 & 3,34 \\
\hline \multirow[t]{4}{*}{ Ölçme değerlendirmede yaşanan sorunlar } & $0-5$ yil & 6 & 18,00 & 4,04 \\
\hline & 6-10 y1l & 8 & 19,87 & 2,74 \\
\hline & $11-15$ y1l & 15 & 21,80 & 3,38 \\
\hline & 16 yıl ve üzeri & 21 & 22,00 & 4,14 \\
\hline \multirow[t]{4}{*}{ Dersle ilgili yaşanan sorunlar } & $0-5$ yil & 6 & 11,83 & 3,25 \\
\hline & $6-10$ y1l & 8 & 13,00 & 2,00 \\
\hline & $11-15$ yil & 15 & 12,66 & 2,96 \\
\hline & 16 yıl ve üzeri & 21 & 13,90 & 2,40 \\
\hline \multirow[t]{4}{*}{ Öğretim programı ile ilgili sorunlar } & $0-5$ yil & 6 & 16,50 & 2,58 \\
\hline & $6-10$ y1l & 8 & 17,00 & 2,92 \\
\hline & $11-15$ y1l & 15 & 18,33 & 3,28 \\
\hline & 16 yıl ve üzeri & 21 & 19,71 & 2,30 \\
\hline \multirow[t]{4}{*}{ Toplam } & $0-5$ yil & 6 & 97,50 & 12,53 \\
\hline & 6-10 y1l & 8 & 102,5 & 9,21 \\
\hline & $11-15$ yil & 15 & 105,3 & 12,92 \\
\hline & 16 yıl ve üzeri & 21 & 111,3 & 10,21 \\
\hline
\end{tabular}

Tablo 7'ye göre, fen ve teknoloji dersi ile ilgili yaşadıkları sorunlara ilişkin puanlar; süreç öncesi sorunlar, süreçteki sorunlar, ölçme ve değerlendirmedeki sorunlar, dersle ilgili sorunlar, öğretim programı ile ilgili sorunlar alt boyutlarında ve ölçme aracının tamamında 16 yıl ve üstü kıdeme sahip olan ögrretmenler için ( $\overline{\mathrm{x}}=23,52)$ en yüksektir. 
Tablo 8. Öğretmenlerin yaşadıkları sorunların güçlük düzeylerinin mesleki kıdemlerine göre ANOVA sonuçları

\begin{tabular}{|c|c|c|c|c|c|c|c|}
\hline & & \multicolumn{2}{|c|}{$\begin{array}{l}\text { Karelerin Sd } \\
\text { Toplamı }\end{array}$} & $\begin{array}{l}\text { Karelerin } \\
\text { Ortalaması }\end{array}$ & $\mathrm{F}$ & $\mathrm{p}$ & Tukey \\
\hline \multirow[t]{3}{*}{ Süreç öncesi sorunlar } & Gruplar arası & 35,374 & 3 & 11,791 & 1,156 & ,337 & \\
\hline & Gruplariçi & 469,046 & 46 & 10,197 & & & \\
\hline & Toplam & 504,420 & 49 & & & & \\
\hline \multirow[t]{3}{*}{ Süreçte sorunlar } & Gruplar arası & 51,457 & 3 & 17,152 & ,993 & 405 & \\
\hline & Gruplar içi & 794,543 & 46 & 17,273 & & & \\
\hline & Toplam & 846,000 & 49 & & & & \\
\hline Ölçme & Gruplararası & 94,005 & 3 & 31,335 & 2,255 & ,095 & \\
\hline değerlendirmedeyaşanan & Gruplar içi & 639,275 & 46 & 13,897 & & & \\
\hline sorunlar & Toplam & 733,280 & 49 & & & & \\
\hline Dersle ilgili & Gruplar arası & 26,044 & 3 & 8,681 & 1,248 & ,303 & \\
\hline \multirow[t]{2}{*}{ Sorunlar } & Gruplar içi & 319,976 & 46 & 6,956 & & & \\
\hline & Toplam & 346,020 & 49 & & & & \\
\hline Öğretim Programı ile İlgili & iGruplar arası & 73,361 & 3 & 24,454 & 3,204 & 032 & $0-5$ yil ile \\
\hline \multirow[t]{2}{*}{ Sorunlar } & Gruplar içi & 351,119 & 46 & 7,633 & & & 16 yıl ve üzeri \\
\hline & Toplam & 424,480 & 49 & & & & arasinda \\
\hline \multirow[t]{3}{*}{ Toplamda Yaşanan Sorunlar } & Gruplar arası & 1134,694 & 3 & 378,231 & 2,998 & ,040 & $0-5$ yil ile 16 \\
\hline & Gruplar içi & 5803,786 & 46 & 126,169 & & & yıl ve üzeri \\
\hline & Toplam & 6938,480 & 49 & & & & arasinda \\
\hline
\end{tabular}

Tablo 8'e göre, öğretim programı ile ilgili sorunlar alt boyutunda ve anketin toplamında kıdem açısından Tukey testi sonuçlarına göre, 0-5 yıl kıdemi olan öğretmenlerle 16 yıl ve üzeri kıdemi olan öğretmenlerin görüşleri arasında anlamlı bir farklılık görülmektedir.

Fen ve Teknoloji dersini yürüten öğretmenlerinin uygulamada karşılaştıkları sorunlar, fen ve teknoloji dersi ile ilgili karşılaşılan sorunlar ve fen ve teknoloji dersi öğretim programıyla ilgili sorunlara ilişskin görüşleri ile görev yeri değişkeni arasında anlamlı bir farklılık var mıdır?

Öğretmenlerin fen ve teknoloji dersi ile ilgili yaşadıkları sorunların güçlük düzeylerinin görev yerine göre t-testi sonuçları Tablo 9' da verilmiştir. 
Tablo 9. Öğretmenlerin fen ve teknoloji dersi ile ilgili yaşadıkları sorunların güçlük düzeylerinin görev yeri değişkenine göre t-testi sonuçları

\begin{tabular}{|c|c|c|c|c|c|c|}
\hline & & $\mathrm{N}$ & $\overline{\mathrm{X}}$ & $\mathrm{SS}$ & $\mathrm{t}$ & $\mathrm{p}$ \\
\hline \multirow[t]{2}{*}{ Süreç öncesi sorunlar } & İlçe Merkezi & 15 & 23,00 & 1,96 & ,660 &, 513 \\
\hline & İl Merkezi & 35 & 22,34 & 3,62 &, 827 & ,413 \\
\hline \multirow[t]{2}{*}{ Süreçte sorunlar } & İlçe Merkezi & 15 & 29,60 & 5,15 & $-1,824$ & ,074 \\
\hline & İl Merkezi & 35 & 31,88 & 3,51 & $-1,569$ &, 132 \\
\hline \multirow[t]{2}{*}{ Ölçme değerlendirmede yaşanan sorunlar } & İlçe Merkezi & 15 & 21,40 & 3,52 & ,332 &, 741 \\
\hline & İl Merkezi & 35 & 21,00 & 4,05 & ,351 & ,728 \\
\hline \multirow[t]{2}{*}{ Dersle ilgili yaşanan sorunlar } & İlçe Merkezi & 15 & 13,93 & 2,89 & 1,395 &, 169 \\
\hline & İl Merkezi & 35 & 12,80 & 2,51 & 1,319 & ,200 \\
\hline \multirow[t]{2}{*}{ Öğretim programı ile ilgili sorunlar } & İlçe Merkezi & 15 & 18,80 & 3,50 & ,499 & ,620 \\
\hline & İl Merkezi & 35 & 18,34 & 2,71 &, 450 & ,657 \\
\hline \multirow[t]{2}{*}{ Toplam } & İlçe Merkezi & 15 & 106,7 & 12,9 & ,098 & ,923 \\
\hline & İl Merkezi & 35 & 106,3 & 11,6 & ,093 & ,926 \\
\hline
\end{tabular}

Tablo 9'a göre, görev yeri değişkeni açısından alt boyutlarda ve anketin tamamında öğretmenlerin fen ve teknoloji dersi ile ilgili yaşadıkları sorunların güçlük düzeyleri puanları arasında anlamlı bir farklılık görülmemektedir.

Fen ve Teknoloji dersini yürüten öğretmenlerinin uygulamada karşılaştıkları sorunlar, fen ve teknoloji dersi ile ilgili karşılaşılan sorunlar ve fen ve teknoloji dersi öğretim programıla ilgili sorunlara ilişkin görüşleri ile öğrenim durumu değişkeni arasında anlamlı bir farklılık var mıdır?

Öğretmenlerin fen ve teknoloji dersi ile ilgili yaşadıkları sorunların güçlük düzeylerinin öğrenim durumlarına göre t-testi sonuçları Tablo 10'da verilmiştir.

Tablo 10. Öğretmenlerin fen ve teknoloji dersi ile ilgili yaşadıkları sorunların güçlük düzeylerinin öğrenim durumlarına göre t-testi sonuçları

\begin{tabular}{lllllll}
\hline & Mezuniyet & $\mathrm{N}$ & $\mathrm{X}$ & $\mathrm{SS}$ & $\mathrm{t}$ & $\mathrm{p}$ \\
\hline Süreç Öncesi Sorunlar & Eğitim fakültesi & 28 & 22,42 & 3,38 &,- 274 &, 785 \\
& Eğitim fakültesi dışı & 22 & 22,68 & 3,04 &,- 278 &, 782 \\
\hline Süreçte Sorunlar & Eğitim fakültesi & 28 & 31,03 & 4,66 &,- 312 &, 756 \\
& Eğitim fakültesi dışı & 22 & 31,40 & 3,50 &,- 323 &, 748 \\
\hline Ölçme Değerlendirmede Yaşanan Sorunlar & Eğitim fakültesi & 28 & 21,21 & 3,78 &, 193 &, 848 \\
& Eğitim fakültesi dışı & 22 & 21,00 & 4,05 &, 191 & .850 \\
\hline Dersle ilgili Yaşanan Sorunlar & Eğitim fakültesi & 28 & 13,25 & 2,66 &, 327 &, 745 \\
& Eğitim fakültesi dışı & 22 & 13,00 & 2,70 &, 326 &, 746 \\
\hline Öğretim Programı ile İlgili sorunlar & Eğitim fakültesi & 28 & 18,32 & 3,30 &,- 426 &, 672 \\
& Eğitim fakültesi dışı & 22 & 18,68 & 2,47 &,- 441 &, 661 \\
\hline
\end{tabular}




\begin{tabular}{lllllll}
\hline Toplamda sorunlar & Eğitim fakültesi & 28 & 106,20 & 12,93 & $-, 153,879$ \\
\cline { 2 - 6 } & Eğitim fakültesi dışı & 22 & 106,77 & 10,65 &,- 156 &, 876 \\
\hline
\end{tabular}

Tablo 10'a göre, öğrenim durumları değişkeni açısından alt boyutlarda ve anketin tamamında öğretmenlerin fen ve teknoloji dersi ile ilgili yaşadıkları sorunların güçlük düzeyleri puanları arasında anlamlı bir farklılık görülmemektedir.

\section{SONUÇ VE TARTIŞMA}

$\mathrm{Bu}$ çalışma Elazığ ilindeki İlköğretim fen ve teknoloji dersini yürüten öğretmenlerin öğretim sürecince yaşadıkları sorunları belirlemeyi amaçlamaktadır. Süreç öncesi, süreç, ölçme değerlendirme, fen ve teknoloji dersi ve öğretim programı alt boyutlarında branş değişkeni açısından anlamlı bir farklılık yoktur. Fakat analiz sonucunda süreç öncesi ve ölçme değerlendirme aşamaları alt boyutlarındaki sorunlarla ilgili olarak, fen ve teknoloji öğretmenlerinin sınıf öğretmenlerine oranla daha fazla güçlük yaşadığı, süreç aşamasındaki sorunlarla ilgili olarak ise, sınıf öğretmenlerinin fen ve teknoloji ögretmenlerine oranla daha fazla güçlük yaşadığı belirlenmiştir. Dede (2006) tarafından yapılan araştırmanın bulgularına göre, öğretmenlerin Fen ve Teknoloji öğretimi ile ilgili yaşadıkları sorunların güçlük düzeylerinin branşa göre, cinsiyete göre, mesleki kıdeme göre ve eğitim düzeylerine göre anlamlı bir şekilde farklılaştığı ortaya çıkmıştır. Eşme (2004) "Fen Öğretiminde Sorunlar" isimli çalışmasında, TIMSS-R sınavının sonuçlarına göre, ülkemizde fen müfredatının yoğun olması (bizde tüm fen konularının \%95'i programlarda yer alırken, sinavda 4. sirada olan Japonya'da bu oran \%62'dir), buna karşı1ık fen eğitimine ayrılan sürenin az olması (fen öğretiminde uluslararası ortalama 122 saat/yıl olmasına karlılık bu süre ülkemizde 87 saat/yıldır), ölçme değerlendirmede daha çok bilgi düzeyi ölçen sorulara yer verilmesi ve ölçme aracı olarak çoktan seçmeli test sınavlarının tercih edilmesi, derslerde, öğrencinin öğrenme sürecinin dışında pasif dinleyici, öğretmenin bilgi aktarıcı olması ve laboratuvara çok az yer verilmesi gibi faktörlerin başarısızlığa neden olduğu belirlenmiştir. Akamca, Hamurcu ve Günay (2006)'ın yaptıkları araştırmada, öğretmenlerin fen ve teknoloji Programına yönelik görüşlerinin genel anlamda olumlu olduğu, nitel verilerin analizinde, öğretmenlerin programla ilgili olarak yeterince bilgilenemedikleri, kaynak konusunda sıkıntılar çektikleri, ölçme ve değerlendirme ile ilgili öğretimin yapılandırılması gibi konularda hizmet içi eğitim almak istedikleri saptanmıştır. Unayağyol (2009), tarafından yapılan araştırmanın bulgularına göre, öğretmenler hala değerlendirme için klasik yöntemlere başvurmakta, performans, proje çalışmalarının ve ürün dosyalarının okullarda etkin bir şekilde kullanılmadığı ortaya çıkmıştır. Özdemir (2005) tarafından yapılan araştırmanın bulgularına göre, öğretmenlerin büyük çoğunluğunun yeni programlarla ilgili herhangi bir hizmet içi eğitim almadığı, yeni programları hiç incelemediği, öğretmenlerin tamamının yeni programlar hakkında görüşlerinin alınmadığı, öğretmenlerin yeni programlarla ilgili bilgi sahibi olma ve yeni programların uygulanması konusunda "kararsız" bir görüşe sahip olduğu ve kendilerini "kısmen yeterli" gördükleri belirlenmiştir. 
Ocak ve Ergün (2006), tarafindan yapılan araştırmanın bulgularına göre, programın yeni olmasına rağmen alternatif ve performans değerlendirme çalışmalarının kullanıldığı, derslerin etkinliklere dayalı olmasından dolayı öğrencilerin büyük bir kısmının fen ve teknoloji dersine katılmaktan hoşlandığı ve edindikleri bilgileri günlük hayatlarında kullandıkları sonucuna varılmıştır. Ayrıca genel olarak ögrenciler tarafindan etkinliklerin yapıldığı ve bu etkinlikler vasıtası ile kazanılan bilgilerin daha kalıcı olduğu görüşüne ulaşılmıştır. Bulut ve Gömleksiz (2007), tarafindan yapılan araştırmanın bulgularına göre, programda öngörülen kazanımlar, kapsam, eğitim durumu ve değerlendirmenin uygulamada "çok" düzeyinde etkili olduğu ortaya çıkmıştır. Tabak (2007) tarafından yapılan araştırmanın bulgularına göre, programın uygulanmasını güçleştiren faktörlerin ne olduğu betimlenmeye çalışılmış ve yeni programda öğrencilerin içeriğin seçimi ile ilgili karar sürecine daha fazla katıldığı, öğretmenlerin programın öngördüğ̈̈ yöntem ve teknikleri süreçte kullanmakta olduğu ancak zaman yetersizliği ve materyal eksikliği gibi bazı faktörlerin programın uygulanmasını zorlaştırdığı sonucuna varılmıştır. Ercan ve Altun (2005), tarafindan yapılan araştırmanın bulgularına göre, öğretmenler, yeni programın olumlu yönleri olarak araştırıcı sorgulayıcı öğrenciler yetiştirilmesi, öğrenci merkezli olması, her öğrencinin her etkinliğe katılarak kendini ifade edebilmesi, konu yoğunluğunun ve öğrenciler arasındaki seviye farkının azalması nedeniyle daha homojen sınıfların oluşturulması gerektiğini belirtmişlerdir. Programla ilgili olarak ta öncelikli olarak hizmet içi eğitimlerin zamanının uygun olmadığı ve süresinin kısa olduğunu, ayrıca konular verilirken uygulamaya yeterince yer verilmediğini, özellikle alternatif ölçme değerlendirme tekniklerinin nasıl uygulanacağına ilişkin detaylı örneklerin verilmediğini, programın etkili uygulanmasını engelleyen diğer bir etmenin de velilerin eğitim anlayışları ve değişimi kabul etmede zorlanmaları olduğu ortaya çıkmıştır. Fernandez ve Ritchie (1992) tarafından yapılan araştırmada, öğretmenlik mesleğine yeni başlayan öğretmenlerin, daha eski olan öğretmenlere oranla fen bilgisi eğitimine karşı istekli oldukları ve kendilerini mesleklerine adadıkları görülmüştür. Bir yıl boyunca devam etmiş olan bu çalışmalarla birlikte zaman geçtikçe öğretmenlerin kullanmış oldukları yöntemlerde değişiklikler olduğu tespit edilmiştir. Yılsonunda ise; öğretmenler, kendi savundukları çözümlerin geleneksel yöntemlere oranla daha faydalı olduğuna inandıkları tespit edilmiştir. Yager (1995) çalışmasında, programların bütün ortaokullarda reforma gidilerek fen-teknoloji-toplum öğretim yaklaşımını ön plâna alması gerektiği ve yapılandırmacı öğretmenlerin reformu yerine getirmeleri için okullarda program ve amaçlar bakımından yeni yapılanmanın oluşması gerektiğini ileri sürmüştür. Mackinnu (1991) tarafından gerçekleştirilen çalışmada, FTT (fen-teknoloji-toplum) yoluyla öğretilen derslerde; süreç, uygulama ve yaratıcılık alanları bakımından, ders kitabıyla öğretim yapılan sınıflara göre, daha yüksek başarı elde edilmiştir. Arslan (2000) tarafindan ülkemizdeki sınıf öğretmenlerinin, Fen Bilgisi derslerini isleme sürecinde çok sayıda sorunla karşılaştıkları; fen alanında kendilerini yeterli hissetmedikleri, laboratuvar uygulamalarını istenilen seviyede gerçekleştiremedikleri yönünde bulguların mevcut olduğu bildirilmektedir.

Araştırma bulgularına göre öğretim programı ile ilgili sorunlarda cinsiyet açısından anlamlı bir farklılık belirlenmiştir. Fakat genel olarak bakıldığında Fen ve Teknoloji dersini yürüten 
öğretmenlerinin uygulamada karşılaştıkları sorunlarda, Fen ve Teknoloji dersi ile ilgili karşılaşılan sorunlarda ve Fen ve Teknoloji Dersi Öğretim Programıyla ilgili sorunlarda cinsiyet değişkeni açısından kadın öğretmenlerin erkek öğretmenlere oranla daha fazla sorun yaşadığı ortaya çıkmıştır. Öztürk (2009) tarafından yapılan araştırmada, öğretmenlerin karşılaştıkları sorunlara ilişkin algılarında cinsiyet değişkeni açısından anlamlı bir farklılığa rastlanmamıştır.

Fen ve Teknoloji dersini yürüten öğretmenlerinin uygulamada karşılaştıkları sorunlarda (Süreç öncesi hazırlıkta karşılaşılan sorunlar, Süreçte karşılaşılan sorunlar, Ölçme değerlendirme etkinliklerinde karşılaşılan sorunlar), Fen ve Teknoloji dersi ile ilgili karşılaşılan sorunlarda ve Fen ve Teknoloji Dersi Öğretim Programıyla ilgili sorunlarda yüksek lisans eğitimi açısından ve 0-5 y1l ile 16 yıl ve üzeri kıdemde olan öğretmenlerin görüşleri arasında anlamlı bir farklılık belirlenmiştir. 16 yıl ve üstü kıdeme sahip öğretmenlerin mesleği tanıma, mesleğin gerektirdiği görevleri öğrenme ve yapılması gerekenleri içselleştirmeleri, örgütsel bağın (örgütsel yapı, kararlara katılabilme firsatları, işte sorumluluk ve özerkliğe sahip olabilme yaş, cinsiyet, hizmet süresi ve eğitim, iş doyumu, işe sarılma, moral ve performans gibi tutumsal, duygusal ve bilişsel yapılar) zamanla oluşmasının yanı sıra, mesleki kıdem arttıkça mesleki bilginin ve tecrübenin de artması sonucunda bu birikimlerinin sonucu olarak 05 yıl, 6-10 yıl ve 11-15 yıl kıdeme sahip öğretmenlerden farklı düşündükleri söylenebilir (Gökyer, 2009).

Görev yeri ve eğitim durumu değişkenleri açısından anlamlı bir farklılık ortaya çıkmamıştır. Fakat süreç öncesi ve dersle ilgili yaşanan sorunlarda il merkezi, süreçte ise ilçe merkezinde görev yapan öğretmenlerin yaşadıkları güçlüklerin daha fazla olduğu görülmektedir. Öztürk (2009) tarafından yapılan araştırmanın bulgusuna göre, öğretmenlerin fen ve teknoloji dersini işlerken karşılaştıkları sorunların düzeyinin, görev yaptığı okulun bulunduğu yere göre anlamlı bir şekilde farklılaştığı belirlenmiştir.

Öneriler

1.Fen ve Teknoloji dersi öğretim sürecinde fen ve teknoloji öğretmenleri ile sınıf öğretmenleri işbirliği yaparak daha etkin bir öğretim süreci sağlanabilir.

2. Fen ve Teknoloji dersinin uygulanmasına ve ölçe değerlendirme ile ilgili tamamlayıcı uygulamalara ilişkin seminer verilip, dersi yürüten öğretmenlerin bilgi ve becerileri arttırılabilir. Eğitim fakültesi mezunu olmayan öğretmenlere çeşitli hizmet içi eğitimler verilebilir.

3. Araştırma öğretmen görüşleriyle sınırlıdır, bu nedenle veli ve yönetici görüşlerine dayalı çalışmalar yapılabilir.

4. Araştırma farklı illerde yapılabilir.

\section{KAYNAKÇA}

Akamca, G. , Hamurcu, H. ve Günay, Y.,(2006) Yeni İlköğretim Fen ve Teknoloji Programına Yönelik Öğretmen Görüşleri, Ulusal Sınıf Öğretmenliği Kongresi, Ankara: Gazi Üniversitesi Yayınları. 
Akdemir, Ö. (2006) İlköğretim II. Kademede Fen Bilgisi Öğretmenlerinin Laboratuar Uygulamalarındaki Yeterlilikleri ve Uygulamalar Sırasında Karşılaşstıkları Sorunlar (Yüksek Lisans Tezi). Furat Üniversitesi Sosyal Bilimler Enstitüsü, Elazı̆̆.

Akgün, Ş. (1995). Fen Bilgisi Öğretimi (5. Baskı). Giresun: Zirve Ofset.

Akgün, Ş. (2000) Öğretmen ve Adaylarına Fen Bilgisi Öğretimi (6. Baskı). Ankara: Pegem-A Yayıncilik.

Arslan, M. (2000). İlköğretim Okullarında Fen Bilgisi Öğretimi ve Belli Başlı Sorunları, IV. Fen Bilimleri Eğitimi Kongresi, Hacettepe Üniversitesi Eğitim Fakültesi, Ankara.

Atasoy, B. (2004) Fen Öğrenimi ve Öğretimi, Ankara: Asil Yayın Dağıtım.

Avc1, Ö. (2006) Van İl Merkezinde İlköğretim İkinci Kademe Fen Bilgisi Öğretiminde Kullanılan Yöntemlerde Karşılaşılan Sorunlar (Yüksek Lisans Tezi). Yüzüncü Yıl Üniversitesi Fen Bilimleri Enstitüsü, Van.

Başaran, İ. E. (1998).Yönetimde İnsan İlişkileri Yönetsel Davranış. Ankara: Aydan Web Tesisleri.

Boyac1, K. (2010). 2005 İlkögrretim 6. 7. ve 8. Sinıf Fen ve Teknoloji Öğretim Programı, Programın Uygulanmasında Yaşanan Sorunlar ve Çözüm Önerilerine İlişkin Öğretmen Görüşleri ( Yüksek Lisans Tezi). Çukurova Üniversitesi Sosyal Bilimler Enstitüsü, Adana.

Bulut, İ. ve Gömleksiz, M. N. (2007). Yeni Fen ve Teknoloji Dersi Öğretim Programının Uygulamadaki Etkililiğinin Değerlendirilmesi, Hacettepe Üniversitesi Ĕ̆itim Fakültesi Dergisi, 32, 76-88.

Çilenti, K. (1984). Fen Öğretiminde Araç, Gereç Kullanımı ve Laboratuar Uygulaması. Ortaöğretim Kurumlarında Fen Öğretimi ve Sorunları. Türk Eğitim Derneği Bilimsel Toplantısı Bildiri ve Tutanakları IV. BİLDİRİ, 12-13 Haziran, Türk Eğitim Dermeği Yayınları Şafak Matbaası, Ankara,

Dede, Z. (2006). Illköğretim Okullarında Fen Bilgisi Dersini Yürüten Öğretmenlerin Fen Bilgisi Dersi Öğretim Sürecinde Yaşadıkları Sorunlar (Nevşehir İli Örneği) (Yüksek Lisans Tezi). Gazi Üniversitesi Eğitim Bilimleri Enstitüsü, Ankara.

Ercan, F. ve Akbaba, A. S. (2005). İlköğretim Fen ve Teknoloji Dersi 4. ve 5. Sinıflar Öğretim Programına İlişkin Öğretmen Görüşleri, Yeni İlköğretim Programları Değerlendirme Sempozyumu, Erciyes Üniversitesi Eğitim Fakültesi - Tekışık Eğitimi Geliştirme Vakfi.

Erdem, M. (2009). 5. Sınıf Fen ve Teknoloji Eğitim Programının Yeterlilikleri ve Karşılaşılan Sorunlara İlişkin Öğretmen Görüşlerinin Belirlenmesi (Yüksek Lisans Tezi). Sakarya Üniversitesi Sosyal Bilimler Enstitüsü, Sakarya.

Eşme, İ. (2004). İlk ve Ortaöğretimde Araştırma Teknikleri ve Proje. İstanbul: Maltepe Üniversitesi Yayınları.

Fernandez, T. S. ve Ritchie, G. (1992). Reconstructingthe Interactive Science Pedegoji: Experiences of Beginning Teachers Implementing the Interactive Science Pedegoji. Research in Science Education (22), 123-131, 
Genç, M. (2001). İlköğretim Okullarının İkinci Kademesindeki Öğrencilerin Fen Bilgisi Dersine Karşı Tutumlarının Değerlendirilmesi (Yüksek Lisans Tezi). Celal Bayar Üniversitesi Fen Bilimleri Enstitüsü, Manisa.

Gökyer, N. (2009). DAUM (Doğu Anadolu Bölgesi Araştırma ve Uygulama Merkezi Dergisi). 8 (1), 68-76.

Kaptan, F. ve Korkmaz, H. (2001) Mevcut Fen Bilgisi Programı ile 2001-2002 Öğretim Y1lında Uygulamaya Konulacak Olan Yeni Fen Bilgisi Programının Karşıllaştırılması, Çağdaş Eğitim Dergisi, (273), 33 - 38.

Keskinkılıç, G. (2010). İlköğretim 7. Sinıf Fen ve Teknoloji Dersinde Uygulanan Yansitıcı Düşünmeye Dayalı Etkinliklerin Bilimsel Süreç Becerilerinin Gelişimine ve Başarıya Etkisi (Yayınlanmamış Doktora Tezi) Selçuk Üniversitesi Eğitim Bilimleri Enstitüsü, Konya.

Kocabaş, Ö. (2004). Fen Bilgisi Öğretmen Adaylarına Fen ve Teknoloji Toplum Dersinin Etkisi ve Öğretmen Adaylarının Derse Karşı Tutumları (Yayınlanmamış Yüksek Lisans Tezi). Gazi Üniversitesi Eğitim Bilimleri Enstitüsü, Ankara.

Kurt, I. (2001). Fen Eğitiminde İşbirlikli Öğrenme Yönteminin Öğrencilerin Başarısına, Kavram Öğrenmesine ve Hatırlamasına Etkisi (Yayınlanmamış Yüksek Lisans Tezi). Marmara Üniversitesi Eğitim Bilimleri Enstitüsü, İstanbul.

Mackinnu,(1991). Comparison of Learning Outcomes Between Classes Taught With A Science Technology and Society (STS) Approachand A Texbook Oriented Approach, The University of lowa, $\mathrm{Ph}$. D. Thesis, http://proquest.umi.com.

Millî Eğitim Bakanlığı (2018). Fen Bilimleri Ders Öğretim Programı. Ankara.

Nakipoğlu ve Özkılıç-Arık, R. (2006). 4. Sınıf öğrencilerinin "gazlar” ile ilgili kavram yanılgılarının vdiyagramı kullanılarak belirlenmesi. Yeditepe Üniversitesi Eğitim Fakültesi Dergisi, 2 (1), 31-46.

Ocak, İ ve Ergün, S. S. (2006). İlköğretim 1. Kademe 4. ve 5. Sınıf Fen ve Teknoloji Dersi Uygulamalarının Öğrenci Görüşlerine Göre Değerlendirilmesi. 15. Ulusal Eğitim Bilimleri Kongresi Bildiri Kitabı, Muğla.

Oğuz, A. (1993). Fen Öğretiminde Ípuçları ve Dönüt Düzeltme İşlemlerinin Erişi Düzeyine Etkisi (Yayınlanmamış Yüksek Lisans Tezi). Anadolu Üniversitesi Sosyal Bilimler Enstitüsü, Eskişehir.

Özdemir, M. S. (2005). İlköğretim Okullarındaki Öğretmenlerin Yeni İlköğretim Programlarına (1-5. Sinıflar) İlişkin Görüşleri, XIV. Eğitim Bilimleri Kongresi, Pamukkale Üniversitesi, Denizli.

Öztürk, Ş. (2009). İlköğretim 4. ve 5. Sınıf Fen ve Teknoloji dersinde Öğretmenlerin Karşılaştıkları Sorunlar (Yayınlanmamış Yüksek Lisans Tezi). Pamukkale Üniversitesi Sosyal Bilimler Enstitüsü, Denizli.

Soylu, H. (2004). Fen Öğretiminde Yeni Yaklaşımlar Keşif Yoluyla Öğrenme, Ankara: Nobel Yayıncılık. 
Tabak, R. (2007) İlköğretim 5. Sinıf Fen ve Teknoloji Ders Programının Öğrenme- Öğretme ve Ölçme Değerlendirme Yaklaşımları Kapsamında İncelenmesi (Yayınlanmamış Yüksek Lisans Tezi ). Muğla Üniversitesi Sosyal Bilimler Enstitüsü.

Tatar, F. (2010). İlköğretim Birinci Kademede Fen ve Teknoloji Dersinin Etkili Yürütülmesi Üzerine Bir Çalışma, Yüzüncü Y1l Üniversitesi Fen Bilimleri Enstitüsü, Van.

Temizyürek, K. (2003). Fen Öğretimi ve Uygulamaları. Ankara: Nobel Yayın Dağıtım.

Terzi, Cemile I. (2008). İlkögretim I. Kademede Fen ve Teknoloji Dersini Yürüten Sinı Öğretmenleri ile II. Kademede Fen ve Teknoloji Dersini Yürüten Fen Bilgisi (Fen ve Teknoloji) Öğretmenlerinin Fen Okuryazarlık Düzeylerinin Belirlenmesi ve Sonuçların Karşılaştırılması (Yayınlanmamış Yüksek Lisans Tezi). Muğla Üniversitesi Sosyal Bilimler Enstitüsü.

Unayağyol, S. (2009).Öğretmenlerin Fen ve Teknoloji Programının Uygulanması Sürecinde Yaşadığı Sorunlar (Yayınlanmamış Yüksek Lisans Tezi). Dokuz Eylül Üniversitesi Eğitim Bilimleri Enstitüsü, İzmir.

Üney, A. (2006). Farklı Branşlardan Mezun Olan Fen Bilgisi Öğretmenlerinin Karşılaştığı Sorunlar, (Yayınlanmamış Yüksek Lisans Tezi). Karadeniz Teknik Üniversitesi Fen Bilimleri Enstitüsü, Trabzon.

Yager, R. E. (1995). Science / Technology / Society: A Reform Arisingfrom Learning Theory and Constructivist Research Association, San Fransisco.

\section{Extended Abstract}

One of the main aims of science education is to carry students to the scientific literacy level. Scientific literacy is defined as to know the nature of natural sciences, to understand how knowledge is obtained, to recognize that information in science is based on known facts and it can change as new evidence is collected, to comprehend the basic concepts, theories and hypotheses in science, to perceive the difference between scientific evidence and personal opinion. Societies of scientifically literate people can easily adapt to innovations, and they can lead innovations themselves. The first systematic learning of students about science concepts begins in Science and Technology courses in 4th grade. However, students' priors learning is very crucial in terms of making their subsequent learning meaningful. Primary 4th and 5th-grade students may have misconceptions due to some misinformation from their daily lives. The misconceptions that will occur in these years will have a negative effect on their learning and will be difficult to change. Teachers should apply methods and techniques that reveal these misconceptions. It is also important that teachers and teachers who apply these methods and techniques be wellequipped as well as the use of methods and techniques in science and technology education. A teacher's world knowledge, knowledge and skills related to his field, as well as the ability to plan and implement the learning process reveals his competence. At this stage, teacher training institutions play a great role. Particularly, they should train their teachers in a more practical and research-based way.

The purpose of this study is to determine the problems faced by science and technology teachers in the primary schools in Elazig. So, the following questions will be answered: 
1. What are the problems teachers face while doing their classes (problems encountered in pre-process preparation, problems encountered during the process, problems in assessment and evaluation activities), regarding the course itself and its curriculum?

2. Do these problems show a significant difference in terms of the branches, gender, graduate education, vocational seniority, place of work and educational status?

This study is of the screening model for direct revealing of teachers' views. The population consists of the science and technology teachers who are working in the primary schools and the classroom teachers of the 4th and 5th grades in Elazig during 2011-2012 academic year. To represent the population, the teachers offering science courses in randomly selected 20 primary schools in Elazig were determined as the sample. The questionnaire was applied to 31 classroom teachers and 19 science and technology teachers. The data collection tool is a 3-point Likert-type scale consisting of 45 items. Scoring of the scale is 3 points for "Yes", 2 points for "Partly“, and 1 point for "No“". The reliability coefficient for the scale was calculated as .89.

In the sub-dimension of the "problems related to the curriculum", it was found that female teachers experience fewer problems than males. Teachers who hold a master's degree state that their problems are of a higher difficulty level than the problems of teachers who don't hold a master's degree. For teachers who have a seniority of 16 years or more, the points related to "the problems related to science and technology course" and in the sub-dimensions of "problems in the process", "problems in measurement and evaluation", "problems related to the course", "problems related to the curriculum", and in curriculum sub-dimension, were all high. According to the findings of the study, the following suggestions can be offered: The knowledge and skills of the teachers who offer science and technology courses can be increased by giving seminars about the application of this course and complementary practices related to measurement assessment. Teachers who are not graduates of education faculties can be given various in-service training. Teachers can determine the level of readiness of the students before the process and prepare appropriate programs for them. Activities that increase the participation of students in the class can be implemented. Teachers can use project-based learning more frequently. In addition, teachers can be encouraged to use the technological equipment effectively. The current study is limited to the views of teachers, so studies based on the views of parents and administrators can be done. 